\title{
EXPERIMENTAL STUDY WITH POND ASH AS PARTIAL REPLACEMENT OF FINE AGGREGATE IN CONCRETE WITH SUPER PLASTICIZER
}

\author{
Prashant Kumar Sharma ${ }^{1}$, Himani ${ }^{2}$, Varsha Dabas ${ }^{3}$ \\ 1Departement of Civil Engineering, Sarvottam Institute of Technology and Management, Greater Noida Extension, \\ Uttar Pradesh, (201009), India \\ 2Departement of Civil Engineering, Sarvottam Institute of Technology and Management, Greater Noida Extension, \\ Uttar Pradesh, (201009), India \\ 3Departement of Civil Engineering, Sarvottam Institute of Technology and Management, Greater Noida Extension, \\ Uttar Pradesh, (201009), India
}

\begin{abstract}
The Energy usufruct and outturn is amplifying day by day due to quick industrialization and urbanization these days. A major section of the energy is originated from Thermal Power Plants. Present scenario of country shows $85 \%$ of country's total power origination is from thermal power plants, of which coal-based generation is around 90\%.During the deflagration of crushed coal at thermal power station the product formed are bottom ash, fly ash, vapors and pond ash. The ash collected from ESP's and the bottom ash with water is disposed in a slurry form in large ponds and dykes which produces Pond ash. In present study the Pond ash has been used as a partial replacement of fine aggregate by weight in ratio of $0 \%(B 0), 5 \%(B 1), 10 \%(B 2), 15 \%(B 3), 20 \%(B 4)$, 25\%(B5). The properties of Pond ash were compared to Fine aggregate. The standard concrete of grade M35 and pond ash mixed concrete of same mix design were compared to understand the mechanical properties of concrete such as compressive strength and workability. A chemical admixture CONPLAST-SP430 is also used for better fulfillment of workability of concrete due to vast dosage of pond ash. The concrete specimens were tested at 3, 7, 14, 28 days of curing period. The Experiments study indicates that Pond ash as a partial replacement of fine aggregate shows beneficiary effects over mechanical properties of concrete. The test results indicate that optimum Pond ash replacement is $15 \%$, where there is a relative increment of compressive strength was obtained up to $13.65 \%$. The bulk density and specific gravity of Pond ash is lower to Fine aggregate causes decrement in unit density of concrete. The main aim of this study is to use hazardous waste by product into building industry to achieve economical and eco-friendly concrete.
\end{abstract}

Keywords: - Bulk density, Specific Gravity,Fine aggregates, Pond Ash, Chemical admixture. ****

\section{INTRODUCTION}

Concrete is world broadly most usufruct development material and is second just to the water as the most used substance on this planet. This can be effectively obtained by joining the cementitious material with water, aggregates or admixtures in specific required extents.

The use of waste materials and by-items in concrete will prompt eco green environment and such concrete can be termed as green concrete. The most generally utilized undesirable materials to supplant bond and sand in concrete are Pond Ash, fly ash, Rice Husk Ash, Blast Furnace Slag, Red Mud, Phosphorus, Gypsum, Silica Fume, Crushed glass, Eggshells and so on. India fundamentally relies on coal for essential of power and its power production is prone to go up from $1,42,095 \mathrm{MW}$ to $3,38,200 \mathrm{MW}$ in year 2015 (as per Study). The fly Ash generation in Indian thermal power stations is liable to shoot up to 365 Million tons.
The burning of lignite or coal in thermal power plant, the comprehensive waste products were Fly ash, bottom ash \& pond ash or mould ash, which are also known as PFA ( Pulverised fuel ash). The fly ash is extracted from fuel gases by electrostatic precipitators. The PFA collected from the bottom of the boiler are termed as Bottom ash. While on mixing the fly ash and bottom ash in water to form slurry and then deposited in pond or lagoon are termed as Pond ash. The Pond ash is a waste product and therefore less expensive as compared to aggregates and can be easily available.

A small percentage i.e. $8 \%$ to $10 \%$ of fly ash is being used in India while in other countries the percentage of utilization is $30 \%$ to $80 \%$. The disposal of fly ash and Pond Ash will be a big challenge to environment. With availability of large amount of pond ash at lower costs for concrete seems to offer the best short term solution to rising aggregate and cement demand. Hence its use in concrete industry is one of 
the effective methods of utilization. Increase in demand and decrease in natural resources of fine aggregate for the production on concrete has resulted in identifying a new source of fine aggregate.

\section{MATERIALS AND METHODS}

Experimental Study: After proper mixing of ingredients, moulds of size $150 \mathrm{~mm} \times 150 \mathrm{~mm} \times 150 \mathrm{~mm}$ were placed on vibrating machine after proper oiling and securely tighten to correct dimension. Proper care was taken that there is no gaps left from where there is any probability of leakage of concrete paste (slurry). Then the concrete is poured in the moulds in three layers. Each layer is left to vibrate for 8-12 seconds to avoid honey combing and moulds are filled up to the brim. After concreting and compaction upper surfaces made smooth with the help of trowel. The moulds were left undisturbed for 24 hours in the laboratory. A total of 81 cubes were casted for the experimental study. All the specimens were casted according to IS 516:1959.

Ordinary Portland Cement: The OPC basically consist of limestone, either of clay, sand or iron and carbonate of magnesia. These materials were grounded and thoroughly blended and heated upto a temperature of $2500^{\circ} \mathrm{C}$ to $3100^{\circ} \mathrm{C}$.Ordinary Portland Cement (OPC) of grade 43 is used in this research project. Cement was tested for chemical and physical properties and is found to be confirming to IS 8112:1989. Table1 shows different properties of cement in tabular form.

Table 1: Physical properties of OPC-43 confirming IS: 8112-1989

\begin{tabular}{|l|l|l|l|}
\hline Sr. No. & Characters & Results & As Per IS:8112-1989 \\
\hline 1. & Specific Gravity & 3.14 & $2.99-3.15$ \\
\hline 2. & Initial Setting Time & 110 Minutes & Min. 30 Minutes \\
\hline 3. & Final Setting Time & 216 Minutes & Max. 600 Minutes \\
\hline 4. & Avg. Specific Area of Cement & $3140.24 \mathrm{~cm}^{2} \mathrm{gm}^{-1}$ & Min. 2250.0 $\mathrm{cm}^{2} \mathrm{gm}^{-1}$ \\
\hline $\mathbf{5 .}$ & Consistency of Cement & $32 \%$ & $32 \%$ \\
\hline 6. & Soundness & $3 \mathrm{~mm}$ & Max. $10 \mathrm{~mm}$ \\
\hline
\end{tabular}

Fine Aggregates: The fine aggregate which was used was locally available river sand, which passed through $4.75 \mathrm{~mm}$. Result of sieve analysis of fine aggregate is given in Table 2 . The specific gravity of fine aggregate is 2.65 and fineness modulus is 2.67 . Bulk density of fine aggregates is 1.29 and compacted bulk density is 1.48 .
Coarse Aggregate: Crushed stones of size greater than $4.75 \mathrm{~mm}$ and passing through $20 \mathrm{~mm}$ sieve conforming to IS 383:1970 were used in the study. Sieve analysis of coarse aggregates is given in Table3. The specific gravity of coarse aggregates is 2.63 and bulk density is 1.5 .

Table 2: Sieve Analysis of Fine Aggregates

\begin{tabular}{|l|l|l|l|l|l|}
\hline IS Sieve & $\begin{array}{l}\text { Average } \\
\text { gms) }\end{array}$ & $\begin{array}{l}\text { \% of wt. } \\
\text { retained }\end{array}$ & $\begin{array}{l}\text { Cum.\% of wt. } \\
\text { retained }\end{array}$ & $\begin{array}{l}\text { \% of } \\
\text { Passing }\end{array}$ & As per IS:383-1970 \\
\hline & & & & & (Zone-2) \\
\hline $\mathbf{1 0 m m}$ & 0 & 0 & 0 & 100 & $\mathbf{1 0 0}$ \\
\hline $\mathbf{4 . 7 5} \mathbf{m m}$ & 98.5 & 9.85 & 9.85 & 90.15 & $\mathbf{9 0 - 1 0 0}$ \\
\hline $\mathbf{2 . 3 6 m m}$ & 53 & 5.3 & 15.15 & 84.85 & $\mathbf{7 5 - 1 0 0}$ \\
\hline $\mathbf{1 . 1 8 m m}$ & 100.5 & 10.05 & 25.2 & 74.8 & $\mathbf{5 5 - 9 0}$ \\
\hline $\mathbf{6 0 0} \boldsymbol{\mu}$ & 143 & 1.43 & 39.5 & 58.5 & $\mathbf{3 5 - 5 9}$ \\
\hline $\mathbf{3 0 0} \boldsymbol{\mu}$ & 406.5 & 40.65 & 80.15 & 19.85 & $\mathbf{8 - 3 0}$ \\
\hline $\mathbf{1 5 0} \boldsymbol{\mu}$ & 173 & 1.73 & 97.45 & 2.55 & $\mathbf{0 - 1 0}$ \\
\hline $\mathbf{7 5} \boldsymbol{\mu}$ & 19 & 1.9 & 99.35 & 0.65 & - \\
\hline $\mathbf{P A N}$ & 6.5 & 0.65 & 100 & 0 & - \\
\hline
\end{tabular}

Table 3: Sieve Analysis of $20 \mathrm{~mm}$ Coarse Aggregates (Single Graded Aggregate

\begin{tabular}{|l|l|l|l|l|l|}
\hline $\begin{array}{l}\text { Sieve Size } \\
(\mathbf{m m})\end{array}$ & Avg. & $\begin{array}{l}\text { \% of Wt. } \\
\text { Retained }\end{array}$ & $\begin{array}{l}\text { Cum. \% of Wt. } \\
\text { retained }\end{array}$ & \% of passing & As per IS 383:1917 \\
\hline $\mathbf{2 0}$ & 109 & 10.9 & 10.9 & 89.1 & $85-100$ \\
\hline $\mathbf{1 0}$ & 852 & 85.2 & 96.1 & 14.8 & $0-20$ \\
\hline $\mathbf{4 . 7 5}$ & 39 & 3.9 & 100 & 0 & $0-5$ \\
\hline PAN & 0 & 0 & 100 & 0 & - \\
\hline
\end{tabular}


Pond Ash: When the bottom and fly ash are thoroughly mixed with water, forming slurry and then was drained out in ponds then it is referred to be as Pond fly ash which is slightly coarser in size as compared to the rest. Different chemical properties are tabulated in Table 3.14 as provided by NTPC Data Records.

Table 4: Physical Properties of Pond Ash

\begin{tabular}{|l|l|l|}
\hline Sr. No. & Properties & Results obtained \\
\hline 1. & Specific Gravity & 1.69 \\
\hline $\mathbf{2 .}$ & Bulk Density $(\mathrm{kg} / \mathrm{l})$ & 1.15 \\
\hline $\mathbf{3 .}$ & Water Absorption $(\%)$ & 1.8 \\
\hline $\mathbf{4 .}$ & Fineness modulus & 3.01 \\
\hline
\end{tabular}

Physical and chemical properties of pond ash are tabulated in Table- 4 and Table- 5 respectively and Table- 6 includes the result of sieve analysis of pond ash.

Table 5: Chemical Properties of Pond Ash

\begin{tabular}{|l|l|l|}
\hline Sr. No. & Compounds & \% Composition \\
\hline 1. & $\begin{array}{l}\text { Silicon di oxide }\left(\mathrm{SiO}_{2}\right) \text { plus, Aluminum oxide }\left(\mathrm{Al}_{2} \mathrm{O}_{3}\right) \text { Plus, Iron Oxide } \\
\left(\mathrm{Fe}_{2} \mathrm{O}_{3}\right) \text { percent by mass }\end{array}$ & 79.97 \\
\hline 2. & Silicon di oxide $\left(\mathrm{SiO}_{2}\right)$ percent by mass & 36.22 \\
\hline 3. & Magnesium oxide $(\mathrm{MgO})$ percent by mass & 2.73 \\
\hline 4. & Total Sulphur as Sulpur Tri-oxide $\left(\mathrm{SO}_{3}\right)$ percent by mass & 0.69 \\
\hline 5. & Available alkalis as Sodium oxide $\left(\mathrm{Na}_{2} \mathrm{O}_{3}\right)$ percent by mass & 2.12 \\
\hline 6. & Loss on ignition percent by mass & 6.84 \\
\hline 7. & Moisture content percent by mass & 1.78 \\
\hline
\end{tabular}

*Provided by NTPC data Records

\begin{tabular}{|c|c|c|c|c|}
\hline \multirow{3}{*}{ Sr. No. } & & le 6: Sieve Analysi & of Pond A & \\
\hline & \multirow[t]{2}{*}{ IS Sieve Sizes } & \multirow[t]{2}{*}{ Percentage Finer } & \multicolumn{2}{|c|}{$\begin{array}{l}\text { Percentage Passing as per } \\
\text { IS383:1970 }\end{array}$} \\
\hline & & & Zone II & Zone III \\
\hline 1. & $4.75 \mathrm{~mm}$ & 100 & $90-100$ & $90-100$ \\
\hline 2. & $2.36 \mathrm{~mm}$ & 86.5 & $75-100$ & $85-100$ \\
\hline 3. & $1.18 \mathrm{~mm}$ & 79.1 & $55-90$ & $75-100$ \\
\hline 4. & $600 \mu$ & 64.54 & $35-59$ & $60-79$ \\
\hline 5. & $300 \mu$ & 18.62 & $8-30$ & $12-40$ \\
\hline 6. & $150 \mu$ & 6.54 & $0-10$ & $0-10$ \\
\hline
\end{tabular}

Table 7: Sieve analysis of Pond ash mixed with Fine Aggregate

\begin{tabular}{|l|l|l|l|l|l|l|}
\hline \multirow{2}{*}{ Sieve Sizes } & \multicolumn{6}{|l|}{ Percentage Passing } \\
\cline { 2 - 7 } & B 0 & B 1 & B 2 & B 3 & B 4 & B 5 \\
\hline $\mathbf{4 . 7 5} \mathbf{~ m m}$ & 90.15 & 92.5 & 94.60 & 95.2 & 96.75 & 98.60 \\
\hline $\mathbf{2 . 3 6} \mathbf{~ m m}$ & 84.85 & 88.25 & 98.63 & 96.75 & 97.92 & 97.12 \\
\hline $\mathbf{1 . 1 8} \mathbf{~ m m}$ & 74.8 & 73.1 & 75.32 & 73.85 & 76.25 & 89.22 \\
\hline $\mathbf{6 0 0} \boldsymbol{\mu}$ & 58.5 & 54.2 & 50.04 & 52.1 & 55.85 & 74.76 \\
\hline $\mathbf{3 0 0} \boldsymbol{\mu}$ & 19.85 & 16.22 & 22.94 & 16.75 & 22.82 & 38.55 \\
\hline $\mathbf{1 5 0} \boldsymbol{\mu}$ & 2.55 & 4.45 & 7.62 & 6.22 & 7.8 & 8.75 \\
\hline Grading & II & II & II & II & II & III \\
\hline
\end{tabular}


The above Table 7 shows the test results of sieve analysis of various specimen when fine aggregate is replaced by pond ash.

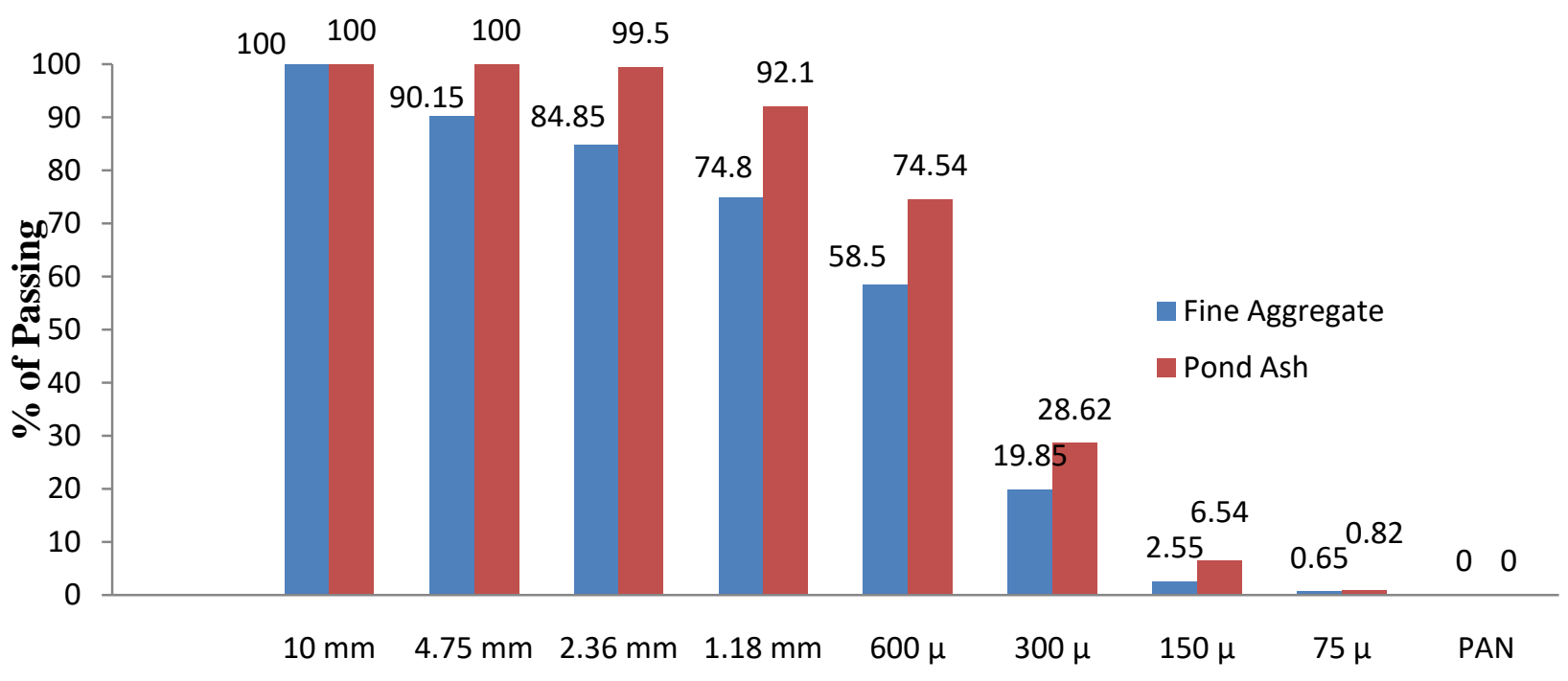

Fig 1: Comparison of sieve analysis of FA and PA

In comparison to FA in which the percentage of water absorption was found to be $0.81 \%$ the percentage of water absorption in the case of PA was found to be $1.18 \%$. The bulk density and specific gravity of PA was found to be less (1.115 and 1.69 respectively) in comparison to FA whose bulk density and specific gravity was calculated as 1.29 and 2.61 respectively.

Chemical Admixtures (CONPLAST- SP430): After the practical investigation over Pond ash, it is found that due to low bulk density, fineness modulus and specific gravity the overall unit mass of concrete was very low and due to which the water absorption value of concrete increases, so in order to compensate these effects the use of water reducing Super plasticizer came to play.
Conplast-SP430 is a concrete admixture manufactured by Fosroc chemicals is basically water reducing admixtures which controls the $\mathrm{W} / \mathrm{C}$ ratio and provides early strength and durability to the concrete, in this project the rate of early strength gaining is up to $30 \%$ was achieved.

Water: Potable water was used for mixing and curing.

Mix Design: Design mix proportion of 1:2.27:2.91 at w/c ratio of 0.40 were used for M35 grade concrete and cement content was $370 \mathrm{~kg} / \mathrm{m}^{3}$ satisfying all the basic requirement as per IS:10262-2009. Six mix proportions are made. So in this research work we will replace the fine aggregate with pond ash partially in percentage of $0 \%, 5 \%, 10 \%, 15 \%, 20 \%$ and $25 \%$ named as $\mathrm{B} 0, \mathrm{~B} 1, \mathrm{~B} 2, \mathrm{~B} 3, \mathrm{~B} 4, \mathrm{~B} 5$ respectively. The Mix proportions are shown in Table-8.

Table 8: Batch Mix Proportions

\begin{tabular}{|l|l|l|l|l|l|l|}
\hline M35 & B0 & B1 & B2 & B3 & B4 & B5 \\
\hline Cement (Kg) & 370 & 370 & 370 & 370 & 370 & 370 \\
\hline Water (Kg) & 148 & 148 & 148 & 148 & 148 & 148 \\
\hline CA (Kg) & 1078 & 1078 & 1078 & 1078 & 1078 & 1078 \\
\hline FA (Kg) & 841 & 798.95 & 756.90 & 714.85 & 672.80 & 630.75 \\
\hline Admixture(Kg) & 3.7 & 3.7 & 3.7 & 3.7 & 3.7 & 3.7 \\
\hline W/C & 0.40 & 0.40 & 0.40 & 0.40 & 0.40 & 0.40 \\
\hline Pond Ash (Kg) & 0.0 & $42 . .05$ & 84.1 & 126.15 & 168.20 & 210.25 \\
\hline
\end{tabular}

\section{RESULT AND DISCUSSION}

The freshly prepared concrete mixes were tested for its workability through Slump test. The tests were performed as per IS 1199-1959. The ease with which one can work with concrete is called workability. Slump cone test is a simple and popular test extensively used at science to assist the workability of the concrete mix. In Table-9 we can see the slump of different mixes of concrete and how gradually it decreases as we increase the pond ash content into concrete. 
The value of slump start decreases, this is due to the fact that the size of pond ash particles are coarser as compared to fine aggregates. The specific gravity and bulk density of pond ash is less as compared to fine aggregate result it into depletion in unit density and weight of concrete. To sustain the unit weight of concrete and to obtain the workability, admixture is required to provide the sustainability to the ponded ash concrete and to acquire a reasonable slump throughout the batch mixes.

Table 9: Slump variation with different concrete mix proportions

\begin{tabular}{|l|l|l|l|l|l|l|l|l|}
\hline Sr. No. & $\begin{array}{l}\text { Mix } \\
\text { Designation }\end{array}$ & $\begin{array}{l}\text { Cement } \\
(\mathbf{K g})\end{array}$ & $\begin{array}{l}\text { CA } \\
(\mathbf{K g})\end{array}$ & $\begin{array}{l}\text { FA } \\
(\mathbf{K g})\end{array}$ & $\begin{array}{l}\text { PA to FA } \\
(\boldsymbol{\%})\end{array}$ & $\begin{array}{l}\text { PA } \\
(\mathbf{K g})\end{array}$ & $\begin{array}{l}\text { Water } \\
(\mathbf{K g})\end{array}$ & $\begin{array}{l}\text { Slump } \\
(\mathbf{m m})\end{array}$ \\
\hline 1. & B 0 & 370 & 1078 & 841 & 0 & 0 & 148 & 148 \\
\hline 2. & B 1 & 370 & 1078 & 798.95 & 5 & 42.05 & 148 & 137 \\
\hline 3. & B 2 & 370 & 1078 & 756.90 & 10 & 84.10 & 148 & 130 \\
\hline 4. & B 3 & 370 & 1078 & 714.85 & 15 & 126.15 & 148 & 122 \\
\hline 5. & B 4 & 370 & 1078 & 672.80 & 20 & 168.20 & 148 & 114 \\
\hline
\end{tabular}

From figure 2, we can illustrate that as we add the pond ash the value of slump start decreases, this is due to the fact that the size of pond ash particles are coarser as compared to fine aggregates. The specific gravity and bulk density of pond ash is smaller as to the fine aggregate result it into depletion in unit density and weight of concrete. To sustain the unit weight of concrete and to obtain the workability, admixture is required to provide the sustainability to the ponded ash concrete and to acquire a reasonable slump throughout the batch mixes. These slump values are average slump values of each batch mix.

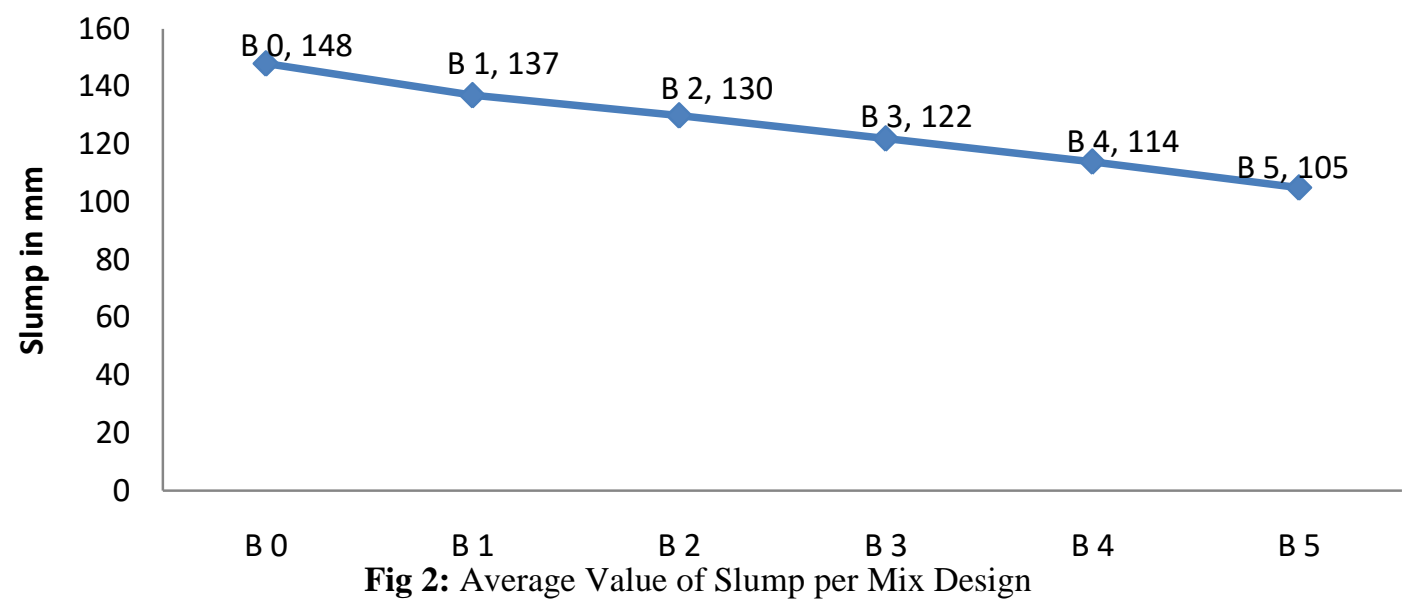

As we increase the dosage of Pond ash, the overall density of concrete and unit weight of concrete comparatively decreases and the water requirement into concrete increases for concrete flow. So to maintain the water cement ratio in concrete a water reducing admixture play an important role while adding pond ash into concrete. As we increases the pond ash the slump decreases, and to sustain the slump value in a limited range the dosage of admixture gradually increases since the characteristic physical properties of pond ash is lower than that to the fine aggregate used in this project.

Table 10: Admixture content in different Batch mixes

\begin{tabular}{|l|l|l|l|l|l|l|l|}
\hline S. No. & $\begin{array}{l}\text { Batch } \\
\text { Mix }\end{array}$ & $\begin{array}{l}\text { Cement } \\
(\mathbf{K g})\end{array}$ & $\begin{array}{l}\text { Water } \\
(\mathbf{K g})\end{array}$ & $\begin{array}{l}\text { CA } \\
(\mathbf{K g})\end{array}$ & $\begin{array}{l}\text { FA } \\
(\mathbf{K g})\end{array}$ & $\begin{array}{l}\text { PA } \\
(\mathbf{K g})\end{array}$ & $\begin{array}{l}\text { Admixture } \\
\text { Content }(\mathbf{K g})\end{array}$ \\
\hline 1. & B 0 & 9.25 & 3.7 & 26.95 & 21.025 & 0 & 0.0925 \\
\hline 2. & B 1 & 9.25 & 3.7 & 26.95 & 19.975 & 1.05 & 0.1370 \\
\hline 3. & B 2 & 9.25 & 3.7 & 26.95 & 18.90 & 2.10 & 0.1975 \\
\hline 4. & B 3 & 9.25 & 3.7 & 26.95 & 17.875 & 3.15 & 0.2340 \\
\hline 5. & B 4 & 9.25 & 3.7 & 26.95 & 16.820 & 4.205 & 0.3075 \\
\hline 6. & B 5 & 9.25 & 3.7 & 26.95 & 15.769 & 5.256 & 0.3820 \\
\hline
\end{tabular}


Testing of hardened concrete plays very significant role in controlling and confirming the quality and standards of concrete, which helps to understand the integrity and strength of specimen. In present investigation, mechanical properties such as compressive strength by destructive test and unit weight of concrete with and without application of super plasticizer were determined as per relevant Indian Standards.

The unit weight of hardened cube specimens of all the six specimens, after a curing period of 28days without application of super plasticizer were tabulated in
Table11.The percentage reduction in unit weight of cubes specimen shows linear increment as we increases the dosage of pond ash into concrete.

It is observed that as we increases the quantity of pond ash into concrete as a replacement of fine aggregate, the unit weight of concrete starts decreases. From mix B1 to B5 this reduction is found to be ranging from 1.77 to $18.89 \%$, which doesn't stabilizes the concrete for constructional environment. To counterbalance this reduction we have to add super plasticizer to enhance the unit weight of concrete.

Table 11: Average Weight of Cube Specimen of Six Mixes

\begin{tabular}{|l|l|l|l|}
\hline Mix & Mix Content & $\begin{array}{l}\text { Avg. Wt. of Cube Specimen } \\
(\mathrm{Kg})\end{array}$ & \% Reduction in Weight. \\
\hline B 0 & M35 (100\% FA) & 8.47 & - \\
\hline B 1 & M35 (95\%FA + 5\% PA) & 8.32 & 1.77 \\
\hline B 2 & M35 (90\% FA + 10\% PA) & 7.98 & 5.78 \\
\hline B 3 & M35 (85\% FA + 15\% PA) & 7.59 & 10.39 \\
\hline B 4 & M35 (80\% FA + 20\% PA) & 7.18 & 15.23 \\
\hline B 5 & M35 (75\% FA + 25\% PA) & 6.87 & 18.89 \\
\hline
\end{tabular}

The Hardened cube specimens were tested for compressive strength with compression testing machine (CTM) at the age of $3,7,14,28$ days of curing respectively, confirming to IS 516-1959. The cubes were tested in damp condition immediately after removal from water. The specimens were placed on the testing platform of the compression testing machine in such a way, that the load was applied to the surface other than the top and bottom surface as cast. The load was applied and increased gradually until the resistance of the specimen to the increase in load break down and no greater load was sustained. The total load at failure was recorded. The maximum load applied divided by its cross sectional area given the compressive strength. Average of three specimens was taken on each curing days and the results are recorded. In Table 4.4 the compressive strength of Six mixes i.e. B0, B1, B2, B3, B4, B5 were tested at 3, 7, 14, 28 days and are tabulated. The B0 mix was taken as a reference for the other batch mix design for calculation of percentage increment/decrement of strength values.

Table 12: Compressive strength of six mixes at different curing periods by CTM

\begin{tabular}{|c|c|c|c|c|}
\hline Mix & Days & $\begin{array}{l}\text { Compression } \\
\text { Strength Value }\end{array}$ & $\begin{array}{l}\text { Average } \\
\text { Compressive St. }\end{array}$ & $\%$ Increment(+) or \% Decrement (-) \\
\hline \multirow{14}{*}{ B 0} & \multirow{3}{*}{3 Days } & $26.26 \mathrm{MPa}$ & \multirow{3}{*}{ 26.44 MPa } & \multirow{3}{*}{ (+) $0 \%$} \\
\hline & & $27.55 \mathrm{MPa}$ & & \\
\hline & & $25.51 \mathrm{MPa}$ & & \\
\hline & \multirow{4}{*}{7 Days } & $30.22 \mathrm{MPa}$ & \multirow{4}{*}{ 29.91 MPa } & \multirow{4}{*}{$(+) 0 \%$} \\
\hline & & & & \\
\hline & & 27.86 MPa & & \\
\hline & & $31.69 \mathrm{MPa}$ & & \\
\hline & \multirow{4}{*}{14 Days } & $32.50 \mathrm{MPa}$ & \multirow{4}{*}{$31.84 \mathrm{MPa}$} & \multirow{4}{*}{$(+) 0 \%$} \\
\hline & & & & \\
\hline & & $29.87 \mathrm{MPa}$ & & \\
\hline & & $33.15 \mathrm{MPa}$ & & \\
\hline & \multirow{3}{*}{28 Days } & $42.70 \mathrm{MPa}$ & \multirow{3}{*}{$42.87 \mathrm{MPa}$} & \multirow{3}{*}{ (+) $0 \%$} \\
\hline & & $39.80 \mathrm{MPa}$ & & \\
\hline & & $46.11 \mathrm{MPa}$ & & \\
\hline & & $25.75 \mathrm{MPa}$ & & \\
\hline
\end{tabular}




\begin{tabular}{|c|c|c|c|c|}
\hline \multirow{11}{*}{ B 1} & \multirow[t]{2}{*}{3 Days } & $27.10 \mathrm{MPa}$ & \multirow[t]{2}{*}{$26.79 \mathrm{MPa}$} & \multirow[t]{2}{*}{ (+) $1.33 \%$} \\
\hline & & $27.52 \mathrm{MPa}$ & & \\
\hline & \multirow{3}{*}{7 Days } & $31.25 \mathrm{MPa}$ & \multirow{3}{*}{$30.55 \mathrm{MPa}$} & \multirow{3}{*}{ (+) $2.14 \%$} \\
\hline & & $28.75 \mathrm{MPa}$ & & \\
\hline & & $31.65 \mathrm{MPa}$ & & \\
\hline & \multirow{3}{*}{14 Days } & $34.3 \mathrm{MPa}$ & \multirow{3}{*}{$33.89 \mathrm{MPa}$} & \multirow{3}{*}{ (+) $6.44 \%$} \\
\hline & & $32.85 \mathrm{MPa}$ & & \\
\hline & & $34.52 \mathrm{MPa}$ & & \\
\hline & \multirow{3}{*}{28 Days } & $44.2 \mathrm{MPa}$ & \multirow{3}{*}{$43.56 \mathrm{MPa}$} & \multirow{3}{*}{ (+) $1.61 \%$} \\
\hline & & $40.87 \mathrm{MPa}$ & & \\
\hline & & $45.61 \mathrm{MPa}$ & & \\
\hline \multirow{12}{*}{ B 2} & \multirow{3}{*}{3 Days } & $27.20 \mathrm{MPa}$ & \multirow{3}{*}{$27.05 \mathrm{MPa}$} & \multirow{3}{*}{ (+) $2.31 \%$} \\
\hline & & $26.40 \mathrm{MPa}$ & & \\
\hline & & $27.5 \mathrm{MPa}$ & & \\
\hline & \multirow{3}{*}{7 Days } & $30.05 \mathrm{MPa}$ & \multirow{3}{*}{$31.20 \mathrm{MPa}$} & \multirow{3}{*}{ (+) $4.31 \%$} \\
\hline & & $31.55 \mathrm{MPa}$ & & \\
\hline & & $32.0 \mathrm{MPa}$ & & \\
\hline & \multirow{3}{*}{14 Days } & $32.0 \mathrm{MPa}$ & \multirow{3}{*}{$33.90 \mathrm{MPa}$} & \multirow{3}{*}{ (+) $6.47 \%$} \\
\hline & & $33.67 \mathrm{MPa}$ & & \\
\hline & & $36.03 \mathrm{MPa}$ & & \\
\hline & \multirow{3}{*}{28 Days } & $42.71 \mathrm{MPa}$ & \multirow{3}{*}{$43.67 \mathrm{MPa}$} & \multirow{3}{*}{ (-) $2.17 \%$} \\
\hline & & $43.52 \mathrm{MPa}$ & & \\
\hline & & $44.78 \mathrm{MPa}$ & & \\
\hline \multirow{12}{*}{ В 3} & \multirow{3}{*}{3 Days } & $32.60 \mathrm{MPa}$ & & \\
\hline & & $30.70 \mathrm{MPa}$ & $31.80 \mathrm{MPa}$ & (+) $20.27 \%$ \\
\hline & & $32.0 \mathrm{MPa}$ & & \\
\hline & & $35.90 \mathrm{MPa}$ & & \\
\hline & 7 Days & $34.55 \mathrm{MPa}$ & $33.43 \mathrm{MPa}$ & (+) $11.77 \%$ \\
\hline & & $29.84 \mathrm{MPa}$ & & \\
\hline & & $40.80 \mathrm{MPa}$ & & \\
\hline & 14 Days & $36.67 \mathrm{MPa}$ & $38.23 \mathrm{MPa}$ & (+) $20.07 \%$ \\
\hline & & $37.20 \mathrm{MPa}$ & & \\
\hline & & $50.40 \mathrm{MPa}$ & & \\
\hline & 28 Dous & $47.50 \mathrm{MPa}$ & 4872 & (1) $1265 \%$ \\
\hline & 28 Days & $48.30 \mathrm{MPa}$ & $40.12 \mathrm{MIF}$ & (+) $15.05 \%$ \\
\hline & & $31.72 \mathrm{MPa}$ & & \\
\hline & 3 Days & $30.80 \mathrm{MPa}$ & $31.70 \mathrm{MPa}$ & (+) $19.89 \%$ \\
\hline
\end{tabular}




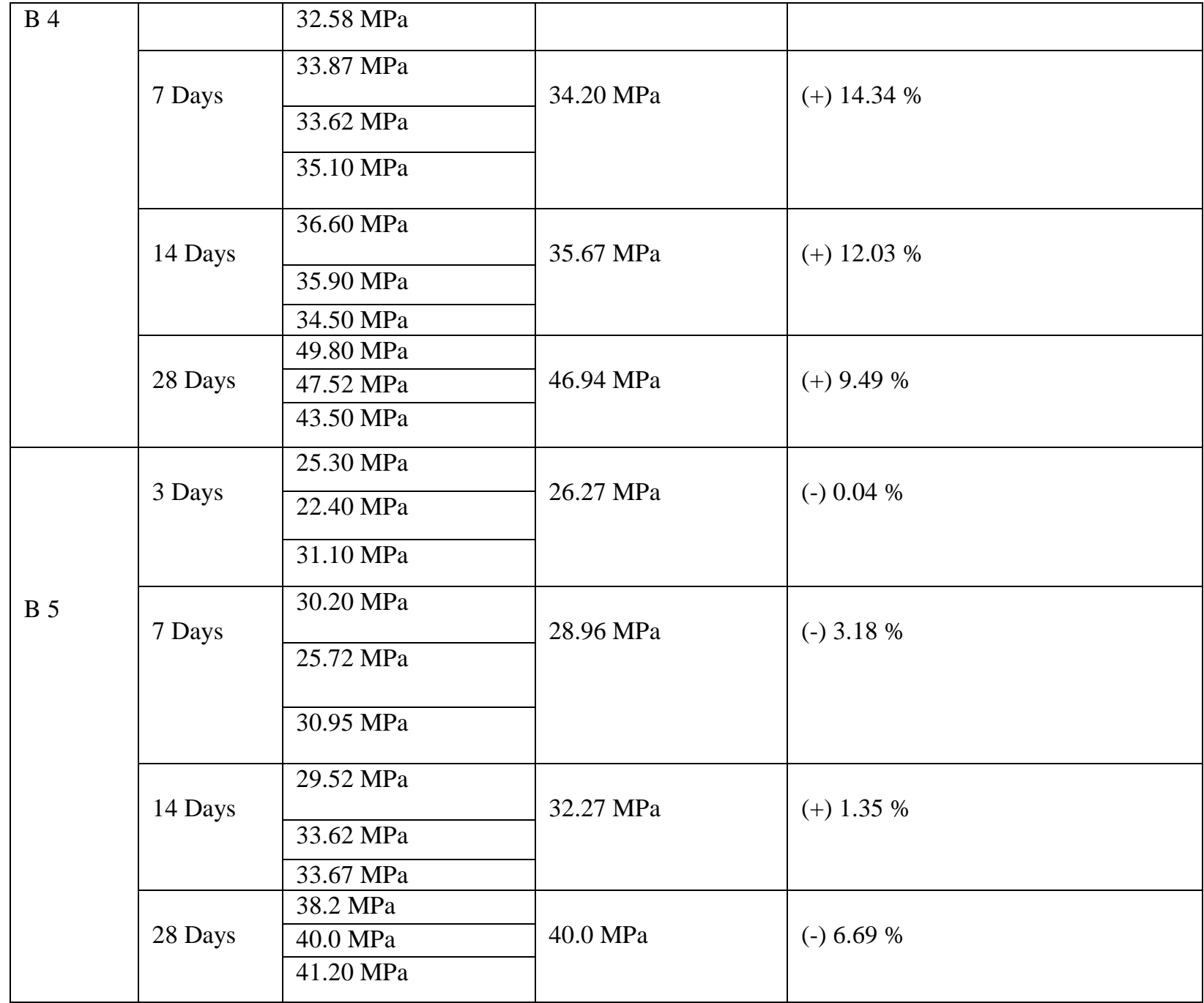

The characteristic strength of concrete is evaluated at 28 days of curing period. From the table 12, the compressive strength value at 28 days of curing increases from B0 to B3 i.e. $42.87 \mathrm{MPa}$ to $48.72 \mathrm{MPa}$ and then decreases from $\mathrm{B} 4$ to $\mathrm{B} 5$. The compressive strength value is higher for B 3 grade mix of concrete which is $48.72 \mathrm{MPa}$ while for standard mix it is 42.87 , which on comparison about $13.65 \%$ more to the standard mix value shown in Figure 4. This increment in compressive strength is due to the effect of admixture and increase in curing periods. It is found that as we increase the curing period, the compressive strength of Pond ash concrete also increases. So addition of pond ash up to $15 \%$ replacement to the fine aggregate is the optimum value of pond ash that could enhance the character of concrete in compressive strength point of aspect. However using admixture to achieve workability and to maintain the unit density of the concrete is the only way to resolve this solution. In graph from Figure 5 shows the compressive strength value of different grade mix of concrete at 7,14 and 28 days of curing.

After further addition of Pond ash i.e. above 15\% (Fig 3) the compressive strength reduces due to the lower bulk density and higher water absorption of pond ash, if compared to fine aggregate. This reduction results that $15 \%$ replacement is the optimum value for Pond ash as partially replaced as Fine aggregate. 


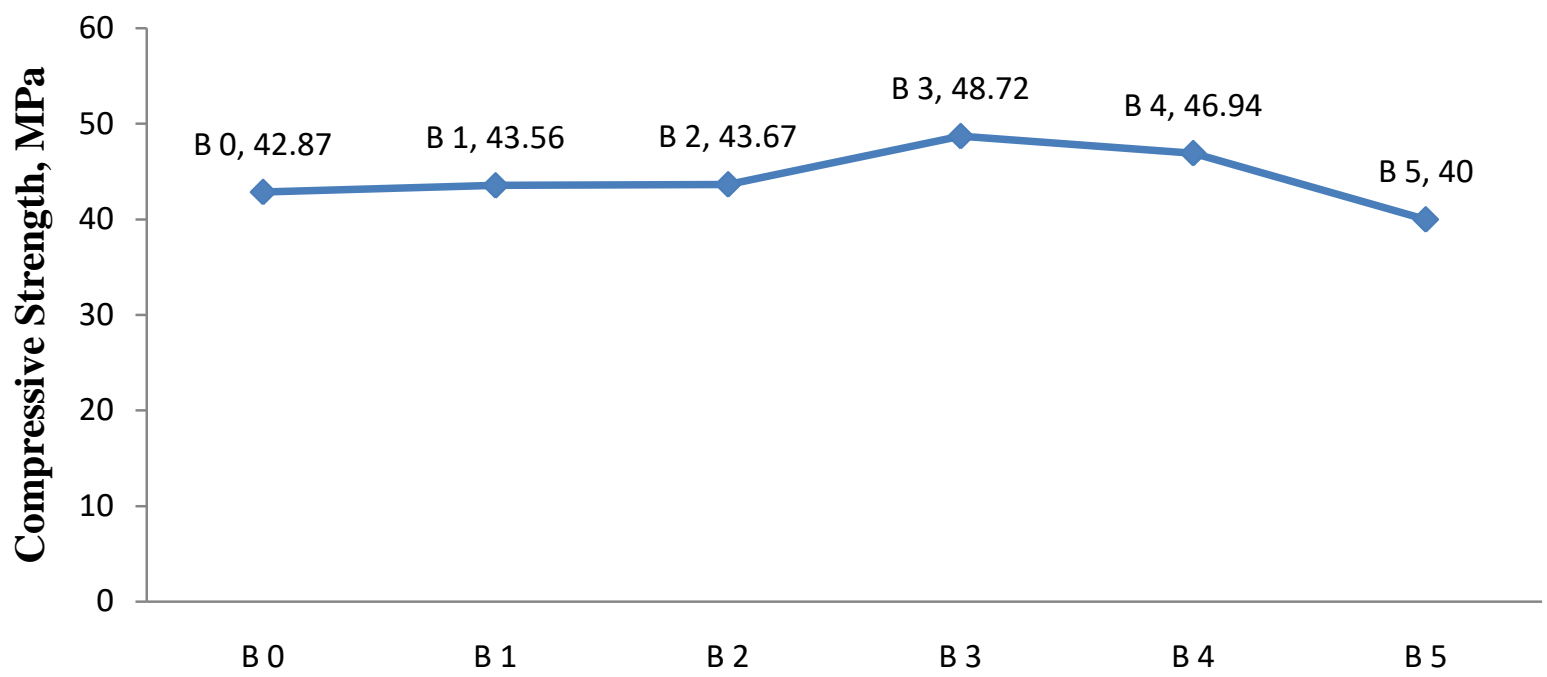

Fig 3: Variation of Compressive strength per Batch Mix at 28 Days

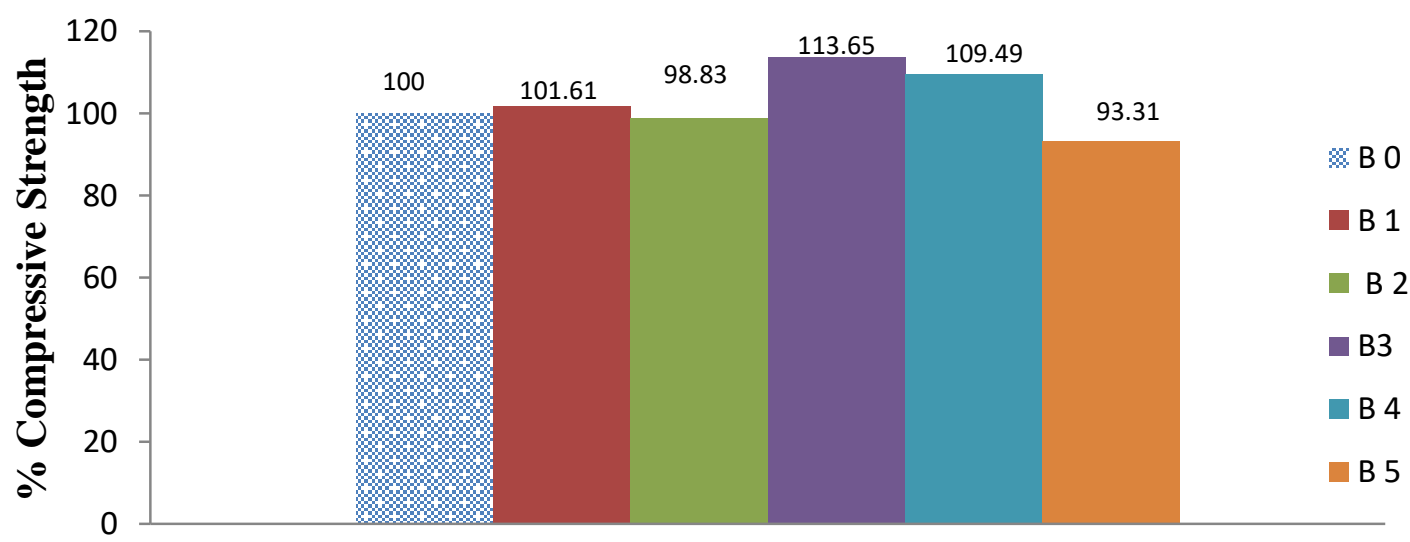

28 Days

Fig 4: Relative Compressive Strength per batch mix at 28 Days

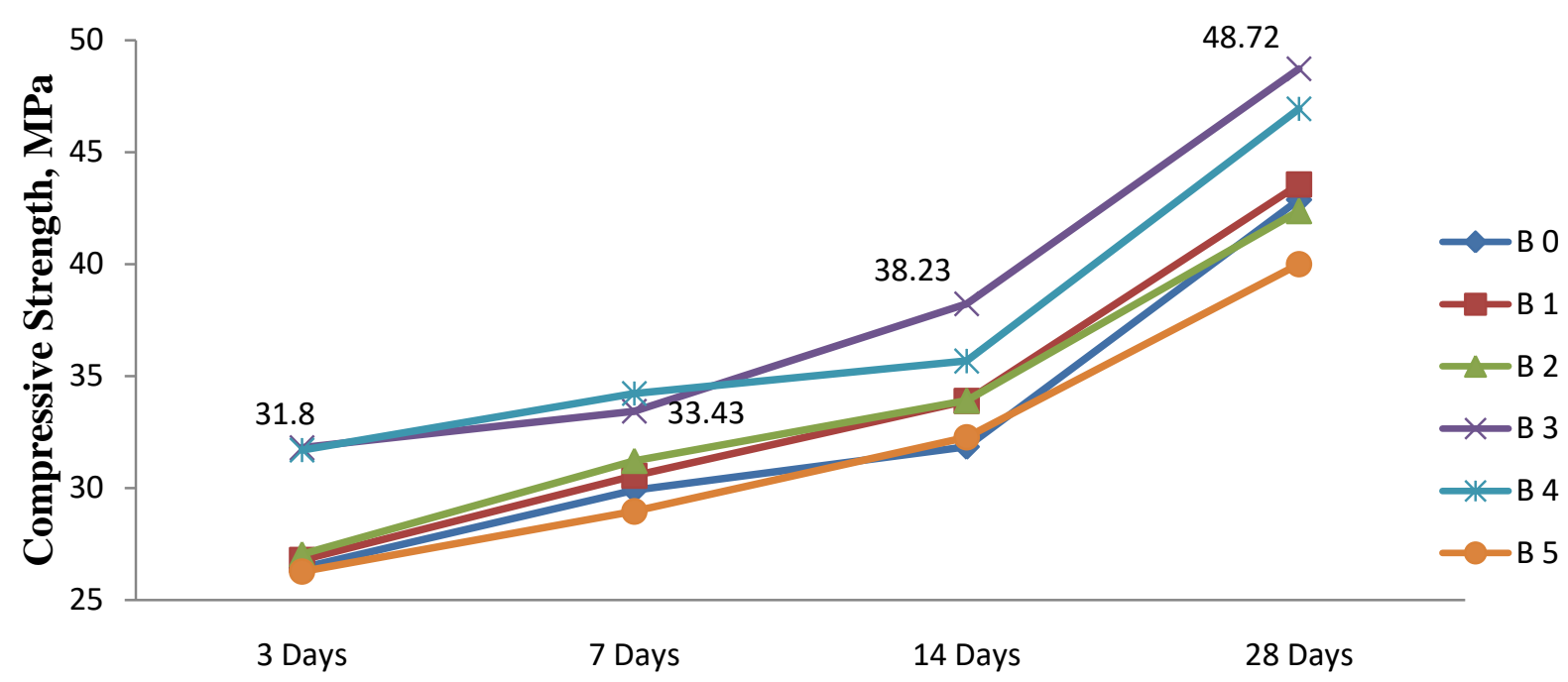

Age (Days)

Fig 5: Variation of Compressive strength of concrete. 


\subsection{Cost Comparison between Pond Ash and Fine}

\section{Aggregate}

The cost of normal weight fine aggregate is Rs.49 per cubic feet whereas the cost of Pond ash is nothing. Pond ash is found to be from National Thermal Power Plants where they were scarily available in bulk amounts. So the cost saving of around $15-20 \%$ can be achieved if replace the fine aggregate with Pond ash. However we can also use lower unit weight ponded ash concrete in construction of partition walls, gap filling, and acoustic insulation where the loading condition doesn't play any major role and the structural element's dead load also decreases by the use of ponded ash concrete.

\section{CONCLUSION}

1. The specific gravity for fine aggregate is 2.61 and for pond ash it is 1.69. So the pond ash satisfies the limit of specific gravity criteria as per IS code. And can also be used to reduce the structural dead weight.

2. On replacement of Pond ash partially with Fine aggregate in mix B1 (5\% replacement), B2 (10\% Replacement), B3 (15\% replacement), B4 (20\% replacement), B5(25\% Replacement), it is observed that the Unit weight of Pond ash Concrete reduces by $1.77 \%$ to $18.89 \%$ respectively in comparison to B0. The unit weight of concrete gets reduced through the addition of pond ash as replacement of fine aggregate since it has lower specific gravity than fine aggregate.

3.The fresh properties of concrete show that as we increase the content of pond ash, the flow characteristic of concrete decreases. This may due to the effect of bulk density and water absorption of Pond ash, which is higher to the fine aggregate.

4. Due to mixing of Super Plasticizer an early strength of about $20 \%$ is achieved at early curing periods for all mixes. And as we increase the Pond ash, the admixture content also increases for making a pumpable concrete (Slump ranges between $85-150 \mathrm{~mm}$ ) and to maintain the water cement ratio. 5. The compressive strength at 28days of curing is found to be increasing from $\mathrm{B} 0$ to $\mathrm{B} 3$ i.e. $42.87 \mathrm{MPa}$ to $48.72 \mathrm{MPa}$ while after further addition of pond ash decreases the compressive strength in B4 and B5 which is $46.94 \mathrm{MPa}$ and 40.0 MPa respectively.

6. The compressive strength of concrete with $15 \%$ Pond ash replacement as fine aggregate has higher strength at 3, 7, 14, 28 days of curing. Hence the optimum replacement of fine aggregate by Pond ash is $15 \%$.

7. The compressive strengths of Ponded ash concrete are equal to or higher than the reference concrete at any given age. The utilization of ponded ash enhances the strength considerably at later ages. The additional benefit in terms of strength can lead to economy.

\section{SCOPE OF THE FUTURE WORK}

1. The behaviour of other strength properties such as tensile strength, elastic modulus, flexural strength, stress-strain characteristic to get a brief understanding.
2. The part replacement of fine aggregate with pond ash for casting the slabs with different end conditions required for required strength values.

3. The flexural strength of beams can also be observed by increasing the beam sizes.

4. By providing different types of reinforcements the flexural strength of beams can also be observed.

\section{BIOGRAPHIES}

[1] Abhishek Jain, Nazrul Islam, "Use of flyash as partial replacement of Sand in Cement Mortar" International journal of innovative research in science, Engineering and technology, Volume2, Issue 5, May2013.

[2] Arumugan k Ilangovan, jamesmanohar, " A Study on Characterization and use of Pond Ash as Fine Aggregate in concrete" International journal of Civil and structural Engineering Volume 2, No2, 2011.

[3] ArunkumarDwivedi, Dhiraj Kumar S.Lal, "Influence of Addition of Pond Ash as Partial Replacement with Sand and Cement on the properties of Mortar" International Journal of Innovative Technology, Volume2, Issue4, March2013.

[4] Ashish Kumar Bera et al., (April,07), "compaction characteristics of pond ash", Journal of materials in Civil Engineeringee, 19(4), pp 349-357.

[5] A.G. Patil, L. Gupta,(Aug2015), "Studies on Strength Characterstics of Pond ash replaced Fibre Reinforced Pavement Quality Concrete" International Journal of Engineering research and Applications, Volume05,Issue-8, pp.34-41.

[6] Bruce A. Dockter et al., (1999), international ash utilization symposium, 1999 centre for use of bottom ash and fly ash in rammed earth construction applied energy research, University of Kentucky.

[7] D. Arunkumar, D.K.S. Lal, "Influence of addition of pond ash as partial replacement with sand and cement on the properties of mortar" International journal of innovative Technology and Exploring Engineering, Volume02,Issue-4, March2013.

[8] GauravKantilal Patel, Prof.JayeshKumarPitroda, “ Assessment of Natural Sand and Pond Ash in Indian Context" International Journal of Engineering Trends nad Technology, Volume 04, Issue 10, Oct2013.

[9] IS 2386 (Part I-VIII) -1960 Indian Standars method for testing concrete, (First revision), Bureau of Indian Standards, New Delhi.

[10] IS 456-2000 Specification for Plain and Reinforced Concrete Code of practice, Bureau of Indian Standards, New Delhi.

[11] IS 516-1959 Methods of Tests for Strength of Concrete, Bureau of Indian Standards, New Delhi.

[12] IS 9103-1999 Specification of Concrete Admixtures, Bureau of Indian Standards, New Delhi.

[13] IS 4031-6 (1988): Methods of physical tests for hydraulic cement, Part 6: Determination of compressive strength of hydraulic cement, Bureau of Indian Standards, New Delhi. 
[14] IS 1199 (1959): Methods of sampling and analysis of concrete, Bureau of Indian Standards, New Delhi.

[15] IS 383-1970 Specification for Corase and fine aggregates from natural sources for concrete, Bureau of Indian Standars, New Delhi.

[16] IS 8112-1989 Specification for 43 grade Ordinary Portland Cement, Bureau of Indian Standards, New Delhi. 